\title{
A Study of Cultural conflict and trauma of the protagonist in
}

\author{
Amitav Ghose's The Glass Palace \\ - Dr.K.Jaya \\ Assistant Professor \\ Department of English \\ Sri Krishna Arts and Science College
}

\begin{abstract}
Amitav Ghosh is one of the most popular novelists of the period, with an amazing intelligence of place, history and politics. Ghosh has joined the ranks of notable novelists such as Monohar Malgonkar, Shashi Tharoor, Khushwant Singh, Salman Rushdie, Chaman Nahal, and others. In Ghosh's novels, one may detect a feeling of historical realism. Ghosh's writings are characterised by a strong desire for strong identifications and race relations. Amitav Ghosh recognises that society must be reformed from problems such as caste system, gender discrimination, ill-treatment of women, child marriages, poverty, exploitation, and demonic tradition, among others. Ghosh's humanistic approach provides voice to the forgotten and lowly women characters in his works. He wants to free the entire world from the squabbles of caste, race, gender, religion, untouchability, and geographical dislocation that obstruct human development. It is also demonstrated how the sacrifices of marginalised and female characters have gone unnoticed in the pages of history. This paper examines the Cultural conflict and trauma of the protagonist in AmitavGhose's The Glass Palace.
\end{abstract}

Keywords: Cultural Conflict, Discrimination, Trauma, Geographical dislocation, exploitation 


\title{
A Study of Cultural conflict and trauma of the protagonist in
}

\author{
Amitav Ghose's The Glass Palace
}

$\begin{array}{ll} & \text { - } \\ & \text { Dr.K.Jaya } \\ & \text { Assistant Professor } \\ & \text { Department of English } \\ \text { INTRODUCTION } & \text { Sri Krishna Arts and Science College }\end{array}$

The term "subaltern" has a long and complicated history. The word means vassals and peasants in late-medieval English. It began to mean "lowest levels in the military" by 1700, implying peasant roots. In the British army, a "subaltern" is now a middle-ranking officer. It is the commissioned officer's rank below captain, and it usually includes the several grades of lieutenant. As a result, the word is always associated with low-ranking individuals. The term "subaltern" refers to a subordinate, inferior, or underling. He is impoverished, meagre, lowly, unimpressive, servile, and cruel. He was regarded as awful and worthless by the privileged society. Novels and histories about military exploits in India and America were written by 1800. They are claimed to have begun writing "from a subaltern point of view." Robert Clive, Warren Hastings, and Thomas Munro all had biographies written by G.R. Gleig. He was a master of the subaltern studies genre. The Great War wreaked havoc on the lives of those who were already disenfranchised. Their sufferings grew in number, attracting the attention of more writers, who began to depict the lives of the underclass in more vivid detail than ever before. During colonialism, the term "subaltern" referred solely to the colonised people. However, this umbrella word today includes those who have been cut off from the majority of privilege and power, such as proletarians, workers, Dalits, sons of Cain, and the oppressed.

In England, at the end of the 1970s, subaltern studies made a strong start. A tiny group of English and Indian historians discussed subaltern issues on a regular basis. The meetings resulted in a proposal to start a new journal in India. By 1993, the group, which consisted of a diverse mix of 
marginalised academics, had gained international acclaim, and Ranajit Guha's multidisciplinary grouping of South Asian scholars inspired a Latin American Subaltern Group. According to David Ludden, Subaltern studies became a hot topic in academic circles on several continents in the 1990s, serving as a weapon, target, lightning rod, hitching post, icon, gold mine, and fortress for scholars from history to political science, anthropology, sociology, literary criticism, and cultural studies. (1-2)

Subaltern studies has sparked both excitement and cynicism in the humanities since its inception in the 1970s. It is a postmodernist offshoot that questioned the underpinnings of contemporary social philosophy and cultural beliefs. Subaltern studies has altered the content of history and reshaped it in order to accommodate and re-center common humanity. However, it became responsible for the history writing approach itself. Both the poor, downtrodden, marginalised, and Sons of Cain, as well as the elite and ruling class, are depicted in subaltern studies. They downplay the dominant class's disproportionate importance while redefining established theories and practises that favour the dominant classes. Subalterns are "those groups in society who are subject to the hegemony of the ruling classes," according to Antonio Gramsci. Peasants, labourers, and other people denied access to hegemonic authority are examples of subaltern classes" (Ashcroft 215). As a literary movement, subaltern studies grew in popularity.

The dimensions of narratology and the concept of narrator and narrative voice in Ghosh's novel The Glass Palace are not dissimilar to those of Western storytellers. Ghosh, on the other hand, is influenced by India's great narrative tradition of story-telling, which has always been much stronger and older. The reader learns about the legendary Glass Palace in Burma at the start of the current novel. The protagonist is Raj Kumar, an eleven-year-old urchin who sees it for the first time and is absolutely amazed by its beauty. Though an eleven-year-old child cannot be trusted, it is clear that the omnipresent narrator here manages the narration and the readers by providing a view of the castle. Before the British troops arrived to take charge, the narrator tells how the palace was stolen and plundered by the Burmese communities. 
The narrator describes people from many countries and cultures who are involved in surprising partnerships. There are conflicts and uprisings. There are discussions about political, cultural, social, and ethical issues. Fortunes and destiny are forged and shattered. The author's rigorous study and craftsmanship are used to present all of this. He accurately and intelligently reports everything. Every detail, such as military manoeuvres, automobile and aircraft models, oil drilling, timber trading, cuisine, clothing, and language, reflects the author's presence.All of these information are historically documented and given through the eyes of various character focalizers by the omnipresent narrator.

The omnipresent narrator describes how the Burmese feared and admired the proud Queen Supayalat, and how the invading British transported the monarch and pregnant queen from Mandalay to remote Rattanagiri in the West East of India without ceremony. It was a bold manoeuvre by the British, who were able to totally humiliate the royal couple. While their land was robbed and exhausted of its priceless natural resources meat, precious jewels, petroleum, and ivory, the king and queen lived in absolute poverty and obscurity in a strange place. However, the most crucial characteristic of the work is that not a single episode in the entire text directly reflects the British. They are always in the background and are introduced into the tale as extras rather than characters.

They have been regarded in the same manner that colonised countries were viewed by 18th and 19th century British writers - as backdrop or as allusions that may influence the narrative style or storey line but have no direct link with the protagonists.It is, in fact, the nation's history as perceived and presented through the eyes of the underclass. It is a famous example of colonial people or colonisers both having a voice, but what makes it even more unusual is that the voice is given by colonised people rather than colonisers. When the ubiquitous narrator sheds light on the lives of local people and the time when British colonisers were just getting started, the authorial presence is clear and quite visible in the early chapters of the novel. 
The historian narrator author has a keen eye for minor details, which he describes in great detail. Queen Supayalat and her mother flanked the king as he walked out of the pavilion. The procession moved slowly through the palace's lengthy halls and over the Hall of Audience's mirrored walls. Past the guard honor's shouldered rifles and the English officers' snapped-off solutes. By the east gate, two carriages were waiting. Just as he was about to enter, the King realised that the ceremonial canopy had seven tiers instead of the nine he was supposed to have. (TGP, No. 43) The Glass Palace is a book that has been well researched. It contains extensive study that the author must have conducted for this project, allowing him to write with greater authority about Burmese life.

He is meticulous in his representation of minutiae, which makes the prose engrossing to read. Raj Kumar is the novel's major character focalizer, and his status as an orphan connects him to the poscolonial identity of a writer. Rukmini B. Nair explains in one of her essays, "The Road from Mandalay: Reflections on Amitav Ghosh's The Glass Palace,” Raj Kumar's symbolic and real orphanhood implies that he must build a family where none exists, as Rukmini B. Nair so aptly observes: In effect, Raj Kumar is confronted with the same problem that the postcolonial author faces... He must unravel the 'existential' conundrum that affects everyone who crosses... the clear distinctions between "national identity" and "family genealogy" Raj Kumar, an orphan without a family, must find relatives to claim his inheritance. Saya John becomes his father, Matthew becomes his brother, and Dolly becomes his soul mate.

Raj Kumar, an Indian by birth, takes care of himself from an early age, grows into a powerful man, builds his fortune in Burma, returns to India to find and marry Dolly, whom he first saw when he was eleven years old, returns to Burma to raise his family, and then returns to India in his later years, after his fortune has been destroyed in war and his elder son and daughter-in-law have been killed. He needs to flee Burma because he is not a native, a Burmese, yet he considers it to be his home for the rest of his life.The King, on the other hand, represents people who, like a philosopher, accept their fate. Queen Supalayat, on the other hand, holds a quite different viewpoint. She sees the colonial 
process as dehumanising. She speaks for people who have suffered the same fate as her. We were the first to be imprisoned in the name of progress, and there will be millions more. This is what awaits us all; this is how we shall all end up as prisoners in plague-stricken shanty cities. You may read a hundred years from now that the gap between the Kingdom of Siam and the plight of our own oppressed kingdom is an indictment of Europe's avarice. (TGP 88)

The narrator employs free direct dialogue between characters. Dolly and her friend Uma had a remarkable talk in which they question accepted beliefs and historical facts. When Uma, the Indian Collector's wife, inquires about Queen Supalayat's brutality, Dolly responds by forcing Uma to consider the matter from her perspective.

"You know, Uma," she said in her softest voice. "Every time I come to your house, I notice that picture you have hanging by your front door..." “Of Queen Victoria, you mean?”(TGP114) “Don’t you sometimes wonder how many people have been killed in Queen Victoria's name? It must be millions wouldn't you say? (TGP 114)

The author's viewpoint on representing dice in art or writing is clearly depicted in this exchange. Later in the narrative, Uma understands her friend's point of view and removes the photograph from her home. When Ghosh emphasises the irony of the circumstance, the authorial presence is clear. He depicts a subjugated Burma where the attitude toward India and the Indians is vastly different from how the Burmese are treated. Though Raj Kumar, an Indian-born figure, is at the heart of the storey, he is far from perfect. He is the representative of those Indians who benefitted from British colonisation and accumulated money and power. Ghosh shows colonialism as a process in which individuals and values are always compromised through the recollections and stream of consciousness of Raj Kumar and other characters. 
Ghosh employs yet another crucial narrative method. It's the way the spotlight changes from one country to the next. Ghosh distributes all of the important characters to Burma, India, and Malaysia, then weaves them together by presenting them as character focalizers. He uses the thread 'history,' rather than 'love,' as the motif that irradiates the opening portion. He enacts a shadow drama with actors that focalize and bring alive the colonial history of the region through the large screen he sets over the stage of South Asia. In The Glass Palace, polyphony manifests itself in a variety of ways. In the text, Ghosh establishes a number of powerful, equally essential, and distinct voices that add to the novel's dynamic heteroglossia. In The Glass Palace, the reader discovers the polyphonic novel's "basic open-endedness." In the novel, there are a lot of memorable characters. The reader notes how some characters have an impact on the others. Raj Kumar's commitment to his business, for example, stems from his Uncle Saya John's influence on him during his adolescent years in Mandalay.

The novel's "multimodality" is demonstrated through the several voices, as well as the authorial voice. Mandalay residents, migrants, palace staff, residents of slums surrounding Queen's Place, and citizens of several nations - India, Burma, Malaysia, Bangladesh, and Singapore - all speak different languages and clearly belong to various social classes and cultural backgrounds. Character focalizers disclose the reality of the British Empire, which is cruel not only towards its subjects but even toward its propagators. These are exploited young English males who are utilised to extend the Empire's control and reinforce its power. To exploit the forest's resources in challenging conditions, British colonialists send their young English men to work in the forest for as long as they can stand the dangerous atmosphere and unfavourable climate. Another prominent voice in the narrative is represented by real-life persona Anana San Suu Kii, who is a leader, a symbol, and a voice of fight against the military's authoritarian reign. In the current conditions, her very existence is the essence of a living character focalizer. Ghosh has used her as a symbol of a growing voice in support of man's dignity and sovereignty as a man. 
Ghosh is firmly anchored in his indigenous storytelling traditions, having been influenced by native writers such as Tagore and Satyajit Ray, as well as Indian storytelling traditions such as Panchtantra and JatakKathas. Simultaneously, we detect the impact of foreign writers such as Proust, Gabriel Gaarica Marquez, and Ford Madox Ford on him. On the one hand, his narrative tactics are in keeping with the Indian oral storytelling tradition, but he is also influenced by sophisticated Western techniques such as multiple narrators' reflections, stream of consciousness interior monologues, and memoirs, to mention a few. The novel incorporates several narrative genres such as realism, fantasy, metaphors, symbols, irony, and magical realism. The novel incorporates a variety of genres and extra literary elements, including history, myth, allegory, and picaresque. Instead of providing a simplified, homogeneous, and monologic depiction of reality, Ghosh strives to emphasis on the enormous complexity of the real world. Polyphony and heteroglossia are effective counter-arguments to homogenization and monologizing.

The novel's key themes include infection, difference and otherness, multiplicity, and fragmentation. Ghosh opposes absolutism and monologism and prefers to explore other options through dialogism. He advocates discursive strategies that allow for the inclusion of diverse perspectives and ideas. The text is truly polyphonic because of the novel's open-endedness, the range of genres, the multiplicity of equally legitimate viewpoints, and the indeterminacy and unfinishedness of the narrative structure. Many voices in the novel have exposed the role of various socio-political institutions in suffocating and curtailing human speech and human rights for their own gain and progress. The Glass Palace by Amitav Ghosh examines the impact of colonialism on the political, social, and cultural lives of now-independent countries such as India, Bangladesh, and Burma.

The stage is told through three generations in this work. This novel is also a study of geographical concepts such as space, distance, and time. Many tales have been intertwined. There 
are numerous personalities, each with their own family sagas, histories, and relationships to one another. Through this work, Ghosh, a great humanist, raises his loud voice against oppression and tyranny. At all levels - political, military, and economic - he opposes man's dominance over man. The novel The Glass Palace is broken into seven sections, each of which highlights different aspects of the novel. The tale begins with the 1885 Anglo-Burmese war. KinwunMingyi and Taingda, two top Burmese ministers, are eager to keep the royal family under surveillance because they expect large sums of money from the English in exchange for bringing over King Thebaw and Queen Supayalat, as well as their families.

Mandalay is the name of this area. The British occupation of Burma is depicted in this section.As the royal family prepares to surrender, the looters — the Burmese people who had previously stood back in terror and admiration — rush in to pillage anything they can find in the palace. Similarly, British soldiers in charge of transporting the king's priceless gems and ornaments from the palace to the ship waiting to transport the royal family to exile steal the valuables.Ghosh pulls back the curtain on human nature to show the raw and ruthless greed that motivates individuals at all levels. This urge to seize and possess is demonstrated to be as common among ordinary Asians as it is among British soldiers, and it is the leitmotif of the great empire builders. Thus, unethical greed is revealed to be the driving force that cuts beyond financial status, racial distinctions, caste, creed, individuals, organisations, and nations in a single amazing moment.

Furthermore, the pillage recounted in the novel's opening scene in the huge frame transcends its literal meaning to become a metaphor for the colonizer's raw and naked avarice, and defines the tone of the novel. The second section is titled Ratnagiri, and it depicts imperialism's disastrous results. The monarchy in Burma came to an end with the expulsion of King Thebaw, and the country became part of the British Empire in India. The two countries and their peoples could never come together since they were bound together by colonial domination. 
As Amitav Ghosh tells the stories of the Burmese people's reactions to these significant historical events and changes, he reveals the people's anger and disapproval, as well as how they began to see themselves reflected in the Indians. The Burmese interpreted the Indians' servility and surrender to the British as a warning to dissuade them from going to such lengths to submit to the British colonial masters' power.

The Money Tree, the third portion, demonstrates how to deal with the second generation. Neel, Rajkumar's son, marries Manju, and Arjun and Dinu are fascinated by the British. Morning Side, the fifth section, covers the aftermath of the Second World War in Malaya. The Front, the penultimate portion, portrays how characters endure as a result of the onset of World War II. The Glass Palace, the novel's final portion, depicts the apex of the Indian National Movement and India's final attainment of independence. If The Glass Palace is read critically, it reveals the novel's soul, the spirit that indicts colonial control. History, fiction, autobiographical records, and memories are all brought together in The Glass Palace. The dilemma of how the past is to be remembered is at the heart of The Glass Palace, according to Ghosh in his letter to the Commonwealth Foundation, in which he withdrew the novel from consideration for an award.

The letter conveys the author's belief that "allowing my book to be absorbed under that particular memorialization of the Empire that posed under the guise of 'the Commonwealth' would be betraying the essence of my book." The colonial experience and memories are tinged with the agony and suffering of the many people who lived through those periods in history.

. MeenakshiMukherji explains;

No one is directly indicted in this novel, not a single person idealized. Yet casually mentioned details get linked across space and time to form haunting patterns, their cumulative effect staying with the reader long after the novel is over. For all its vividness of description and range of human experience, The 
Glass Palace will remain for me memorable mainly as the most scathing critique of British colonialism I have ever come across in fiction (3)

A casual examination of the title may reveal little more than The Glass Palace of the Burmese King, which appears only twice throughout the novel following its brief appearance in the first section. At most, the title may allude to the British's destruction, depredation, and exploitation. However, if one looks past the denotative reference, one will notice the resonance and recall the unmistakable allusion to the Crystal Palace, which was built in England during Queen Victoria's reign to commemorate and reflect the vast British Empire's power, glory, and wealth, and was as fragile and brittle as the glass used in its construction, even as it was meant to mirror the British's remarkable achievement in the colonies.However, the Crystal Palace is strangely as much a symbol of British brilliance as it is of colonial exploitation. In a sense, the British palace was built on the ruins of structures like the Glass Palace. If it weren't for this connection, the title would be meaningless; the work extends beyond depicting the pillage of the Burmese Palace to pointing to exploitation in other British colonies as well.

Ghosh has used material derived from a variety of sources to reconstruct the history of Burma's transition from a kingdom to a republic between 1885 and 1995, the period covered by The Glass Palace: recollections and remembered accounts of his father, uncle, and several other living persons he met; diaries, notes, and official records; history books, and so on. Ghosh attempts to comprehend the past in order to make sense of the present. The past is remembered not as a dead, distant epoch, but as a continuous flow into the present, postcolonial societies of multiethnic, pluralist societies with colonial rulers' imposed nation boundaries and mutations, as well as complex cultural diversities of a long-running political struggle for a democratic and egalitarian system. As a result, Ghosh has focused on this issue in some of his books, including The Glass Palace, which is the most important of his works. 


\section{REFERENCES}

Bhaba, Homi K. The Location of Culture. Routledge, 1994.

Hall, Stewart. Cultural Identity and Diaspora Identity: Community, Culture, Difference.

Jonathan Rutherford(ed.). London: Lawrence and Wishart.1990.Print.

Appadurai, Arjun. "Disjuncture and Difference in the Global Cultural Economy: Theory, Culture, Society. pp.296-297.1990. Print.

AschroftBil, Garetth Griffin, and Helen Tiffin, Ed, Key Concepts in Post-Colonial Studies.

London: Routledge, pp. 68-76. 1999. Print.

---. The Empire Writes Back. Theory and Practice in Post-Colonial Literatures.

London: Routledge, 1989. Print.

Banerjee, Sukanya. New Routes for Diaspora Studies. Ed. Daniel J. Sherman. Indiana: IUP, 2012. Print.

Baral, Kailash C. \&Prafulla C. Kar, ed. Identities: Local and Global. Delhi: Pencraft International, 2003. Print.

Bose, Shiladitya, Pablo. Home and Away: Diasporas. New Delhi: Penguin, 2005. Print.

Brah, Avtar. Cartographies of Diaspora: Contesting Identities. London \& New York: Routledge, 1996. Print.

Chakravarthy, Joya. Indian Writing in English: Perspectives. New Delhi: Atlantic, 2003. Print.

Chua, C. L. "Passage from India: Migration to America in the Fiction of V. S. Naipaul and Bharati Mukherjee: Rewording the Literature of the Indian Diaspora”. Ed. Emmanuel Nelson. West Port: Greenwood Press, 1992. 51-61. Print.

Macaulay, Thomas. Minute on Indian Education. ${ }^{\circ}$ Speeches of Lord Macaulay with his Minute on Indian Education. ed. G.M. Young. Oxford: OUP, 1935.430. Rpt. in Post-Colonial Studies Reader. 
Mayhew, A. The Education of India. London: Faber and Faber, 1928.16-27. 10. James H.R.

Education and statement ship in India, London, $9.1 \& 2$ (1988),

Viswanathan, Gauri. "The Beginnings of English Literary Study in British India,. Oxford Literary Studies", The Post-Colonial Studies Reader.437. 9.1 \& 2 (1987). 